1Dr. MD. Shafiul Alam Consultant Dept. of Paediatric Gastroenterology and Nutrition, Bangabandhu Sheikh Mujib Medical University (BSMMU), Dhaka

${ }^{2}$ Prof. B H Nazma Yasmeen Professor Dept. of Paediatrics Northern International Medical College, Dhaka

${ }^{3}$ Dr. Md Benzamin

Dept. of Paediatric Gastroenterology and Nutrition BSMMU, Dhaka

${ }^{4}$ Dr. Nadia Haq

Consultant

Dept. of Paediatrics

Bangladesh Specialized Hospital (BSH), Dhaka

${ }^{5}$ Dr. Md. Shariful Hasan Medical Officer Dept. of Paediatric Gastroenterology and Nutrition BSMMU, Dhaka

Correspondence Dr. MD. Shafiul Alam Dept. of Paediatric Gastroenterology and Nutrition BSMMU, Dhaka email: alam_nizam@yahoo.com

\title{
Nebulization Practice and use of Antibiotic in the Treatment of Childhood Asthma at the Rural Area
}

\author{
M S Alam ${ }^{1}$, B H N Yasmeen², M Benzamin ${ }^{3}$, N Haq ${ }^{4}$, S Hasan ${ }^{5}$
}

Abstract

Background : Management of childhood asthma is not optimum in our country especially at the community level.

Objectives : The study was conducted to see the nebulization practice in the management of moderate and sever acute asthma in children at the community level.

Methodology : This cross-sectional observational study was conducted in different private clinics and pharmacy of Daudkandi Upazila of Cumilla during the period of November 2017 to March 2018. Total 30 doctors' diagnosed cases of acute exacerbation of moderate and severe asthma between 2-15 years of age were included in this study. Each patient's treatment advice was followed up to see whether the use of nebulized Salbutamol and Antibiotic in the management of acute asthma was appropriate or not. All data were recorded in to a pretested proforma. Data were analyzed manually, and values were expressed as frequency and percentage.

Results : Among the cases $25(83.33 \%)$ cases had moderate and 5 (16.67\%) cases had severe exacerbation of asthma. For nebulization, salbutamol was used to all cases and ipratropium bromide was added to $11(36.7 \%)$ cases. Nebulization frequency was as per national guideline but the ratio of salbutamol respiratory solution to normal saline was not appropriate in most of the cases. Antibiotic was given to all cases and among them parenteral Ceftriaxone was given to $22(73.3 \%)$ cases.

Conclusion : Frequency of nebulization was appropriate but ratio of Salbutamol respiratory solution to normal saline was inappropriate. Antibiotic was given to all cases.

Key words : Acute asthma, Nebulization, Antibiotic.

DOI: https://doi.org/10.3329/nimcj.v11i2.54065

Northern International Medical College Journal Vol. 11 No. 2 January 2020, Page 471-474

\section{Introduction}

Asthma is a global health problem affecting about 300 million people. It is estimated that an additional 100 million people may be affected with asthma by 2025. Worldwide, asthma accounts for about 1 in every 250 deaths. Modern management, which includes patient education, can prevent $80 \%$ of death. ${ }^{1}$

Very few studies on epidemiology of asthma are available from Bangladesh. About 7 million Bangladeshi people (5.2\%) has been suffering from current asthma, more than $90 \%$ of whom do not take modern treatment. ${ }^{2}$ Prevalence of asthma in children $7.4 \%$ in contrast to $5.3 \%$ in adults. $^{3}$

Bronchial Asthma is a chronic inflammatory disorder of the airways associated with airway hyper responsiveness to various stimuli that leads to recurrent episodes of wheezing, breathlessness, chest tightness and coughing particularly at night or in the early morning. ${ }^{4}$ These episodes are often reversible either spontaneously or with treatment and are usually associated with widespread and variable airflow obstruction. $^{5}$

In childhood asthma, there is a wide variation in the symptom prevalence. Severe symptoms are more commonly found in children from less affluent countries and there are more children with any of the symptoms of asthma are found in wealthy countries. ${ }^{6}$

Most of the children with asthma have mild or moderate disease. Adequate control of symptoms is possible through avoidance of 
triggering factors and/or with the help of medications, such as inhaled short-acting $\beta_{2}$-receptor agonists (SABA), inhaled corticosteroids (ICS) and, when needed, the addition of longacting $\beta_{2}$-receptor agonists (LABA) and leukotriene receptor antagonists (LTRA). ${ }^{7,8}$

Exacerbations of asthma are episodes characterized by a progressive increase in shortness of breath, cough, wheezing, or chest tightness, or some combination of these symptoms, accompanied by progressive decreases in lung function i.e., they represent a change from the patient's usual status that is sufficient to require a change in treatment. ${ }^{9}$ Acute exacerbation has been clinically classified as mild or moderate, severe and life threatening exacerbation in children aged 6-11 yrs. and in children aged $5 \mathrm{yrs}$. and younger as mild or moderate and severe or life threatening exacerbation. ${ }^{9}$

Most of the mild or moderate exacerbation cases can be managed well at home with judicious use of nebulized salbutamol and oral corticosteroid and a few cases may require hospitalization for high level care. Patients with severe or lifethreatening condition require hospitalization but while waiting nebulized salbutamol, Oxygen inhalation, oral prednisolone, and if needed inhaled ipratropium bromide can save life. Therefore, aerosolized salbutamol is the main stay of treatment of acute exacerbation of asthma.

Mortality rate in different countries is increasing despite many advances take places in the management of asthma. Worldwide deaths from this condition have reached over 180,000 annually. ${ }^{10}$ Death occurs at two peak age groups in children: pre- school children and teenagers. The most common reason of death from asthma has been delay in seeking medical care. With the early initiation of effective treatment death due asthma is unusual. ${ }^{11-13}$

Management of childhood asthma in rural health care system of our country is not optimum still now. Therefore, the study was conducted in the rural area to see appropriateness of the use of nebulized Salbutamol and Antibiotic in the management of acute asthma.

\section{Materials and Methods}

This cross sectional observational study was conducted in different private clinics and pharmacy of Daudkandi Upazilla of Cumilla during the period of November 2017 to March 2018. Total 30 children with acute asthma were included in this study with purposive sampling. All of them were between 2-15 years of age. Child aged below 2 years and above 15 years of age and having coexisting chronic disease in addition to asthma has been excluded. Cases were classified as moderate and severe exacerbation of acute asthma according to the symptoms criteria and treatment advices given by the physicians.
All relevant data were collected in to a pretested proforma of structured questionnaire. Data including age at onset, exacerbating factors, family history, treatment history, current treatment with nebulization, use of antibiotics were recorded. Data were analyzed manually, and values were expressed as frequency, and percentage. In this study we consider the following operational definitions.

\section{Operational Definitions}

Acute exacerbation: The GINA (Global Initiative for Asthma) guidelines define "acute exacerbations" (asthma attacks or acute asthma) as "episodes of progressive increase in shortness of breath, cough, wheezing, or chest tightness, or some combination of these symptoms, accompanied by decreases in expiratory airflow that can be quantified by measurement of lung function. ${ }^{9}$

Mild or Moderate acute asthma : Clinically mild or moderate acute asthma is considered on the basis of presence of following symptoms: breathlessness, agitation. Pulse rate $\leq 200 \mathrm{bpm}(0-$ $3 y r s$ ) or $\leq 180 \mathrm{bpm}$ (4-5 yrs.) Oxygen saturation $\geq 92 \%$. in patient's aged 5 yrs. and younger. In patients aged between 611 yrs. symptoms included: talks in phrases, prefers sitting or lying, not agitated, respiratory rate increased, accessory muscle not used, pulse rate $100-120 \mathrm{bpm} \mathrm{O}_{2}$ saturation (on air) 90 95\% PEF $>50 \%$ predicted or best. ${ }^{9}$

Severe or Life-threatening asthma : Clinically severe or lifethreatening asthma is considered based on the presence of following symptoms: unable to speak or drink, central cyanosis, confusion or drowsiness, marked sub -costal and/or sub-glottic retractions, oxygen saturation $\geq 92 \%$, silent chest on auscultation, pulse rate $>200 \mathrm{bpm}(0-3)$ or $>180 \mathrm{bpm}$ ( $4-5 \mathrm{yrs}$.) in patient's aged $5 \mathrm{yrs}$. and younger.

In patients aged between 6-11 yrs. symptoms included: talks in words, hunched forwards, agitated, respiratory rate $>30 / \mathrm{min}$. use of accessory muscles, pulse rate $>120 \mathrm{bpm}, 02$ saturation (on air) $<90 \%$ PEF $\leq 50 \%$ predicted or best. $^{9}$

Proper dose and technique: Proper dose and technique was considered when salbutamol solution of .15-.3 mg/kg or.05ml/kg or $2.5 \mathrm{mg}$ nebulizer for 5 years and younger was diluted with normal saline to make it at least $2-3 \mathrm{ml}$ and was given with proper face mask or nasal cannula. For ipratropium bromide appropriate dose was considered $250 \mathrm{mcg}$ was given by nebulizer.

\section{Results}

In our study, among 30 cases $12(40 \%)$ patients were male and $18(60 \%)$ were Female. Thirteen $(43.3 \%)$ cases were in between $2-5$ years of age, 15 (50\%) cases were between 6-10 years and $2(6.7 \%)$ cases were in between $10-15$ years of age. (Table I) 
Table I: Age distribution of study children $(n=30)$

$\begin{array}{lcc}\text { Age } & \text { Cases } & \text { Percentage } \\ 2-5 \text { yrs } & 13 & 43.3 \% \\ 6-10 \text { yrs } & 15 & 50 \% \\ 11-15 \text { yrs } & 2 & 6.7 \% \\ \text { Total } & \mathbf{3 0} & \mathbf{1 0 0 \%}\end{array}$

In this study cases $13(43.3 \%)$ patients had been suffering from acute asthma in 2-5 years age group, $15(50 \%)$ in 6-10 years age group, $2(6.7 \%)$ patients were in $11-15$ years of age. (Table II)

Table II : Study children according to severity of acute exacerbation of asthma $(n=30)$

\begin{tabular}{lccc} 
Age group & $\begin{array}{c}\text { Severe or life- } \\
\text { threatening asthma }\end{array}$ & $\begin{array}{c}\text { Mild or Moderate } \\
\text { asthma }\end{array}$ & $\begin{array}{c}\text { Total } \\
\mathbf{n}(\%)\end{array}$ \\
\hline $2-5$ yrs. & $1(3.3 \%)$ & $\mathbf{n}(\%)$ & \\
$6-10$ yrs. & $2(6.7 \%)$ & $12(40 \%)$ & $13(\%)$ \\
$11-15$ yrs. & $2(6.7 \%)$ & $13(43.3 \%)$ & $15(50 \%)$ \\
\hline
\end{tabular}

Among the precipitating factors, acute respiratory tract infections showed the highest incidence (53.3\%). Remaining were exposure to dust, smoke, cold waves (30\%), emotional upset (10\%), exercise (6.7). (Table III)

Table III : Precipitating factors of acute exacerbation of asthma $(n=30)$

$\begin{array}{lcc}\text { Factors } & \text { Number } & \text { Percentage (\%) } \\ \text { ARI } & 16 & 53.3 \\ \text { Cold dust, smoke } & 9 & 30.0 \\ \text { Emotion } & 3 & 10.0 \\ \text { Exercise } & 2 & 6.7 \\ \text { Total } & \mathbf{3 0} & \mathbf{1 0 0 . 0}\end{array}$

In this study all the cases were treated with nebulized Salbutamol. Among them 19 (63.3\%) patients were treated with only Salbutamol solution. $11(36.7 \%)$ cases were treated with nebulized Salbutamol and Ipratropium Bromide. (Table IV)

Table IV : Pattern of nebulization with salbutamol and ipratropium bromide $(n=30)$

$\begin{array}{lcc}\text { Drugs for nebulization } & \text { Number } & \text { Percentage (\%) } \\ \text { Salbutamol } & 19 & 63.3 \\ \text { Slbutamol+Ipratopium bromide } & 11 & 36.7 \\ \text { Total } & \mathbf{3 0} & \mathbf{1 0 0 . 0}\end{array}$

In this study we found that the frequency of nebulization, which was given 6 hourly in $26(86.7 \%)$ patients and 8 hourly in 4 (13.3\%) patients. (Table V)
Table V : Frequency of nebulization $(\mathrm{n}=\mathbf{3 0})$

$\begin{array}{lcc}\text { Frequency of nebulization } & \text { Cases } & \text { Percentage (\%) } \\ 6 \text { hourly } & 26 & 86.7 \\ 8 \text { hourly } & 4 & 13.3 \\ \text { Total } & \mathbf{3 0} & \mathbf{1 0 0}\end{array}$

Among the 30 cases, nebulization solution was appropriate in $6(20 \%)$ cases and correct technic was found in only in $10(40 \%)$ cases. (Table VI)

Table VI : Appropriateness of solution and technic of nebulization

$\begin{array}{cccc}\text { Nebulized with } & \begin{array}{c}\text { Severe or life- } \\ \text { threatening } \\ \text { asthma } \\ \mathbf{n ( \% )}\end{array} & \begin{array}{c}\text { Mild or } \\ \text { Moderate } \\ \text { asthma } \\ \mathbf{n}(\%)\end{array} & \text { Total } \\ \begin{array}{c}\text { Appropriate solution } \\ \text { (Measured amount of }\end{array} & 1(20 \%) & 5(20 \%) & 6(20 \%) \\ \begin{array}{c}\text { respiratory sol. mixed } \\ \text { proper amount of } \\ \text { normal saline) }\end{array} & & & \\ \begin{array}{c}\text { Appropriate technic } \\ \text { nof }\end{array} & 2(40 \%) & 8(32 \%) & 10(40 \%)\end{array}$

In our study we found that among the 30 cases, 28 (93.3\%) patients were treated with antibiotic according to the advice of the doctor. Out of them 22 (73.3\%) patients were treated with Ceftriaxone, $5(16.7 \%)$ cases were treated with Amoxicillin, 2 $(6.7 \%)$ cases were treated with Ampicillin and Gentamicin, 1 (3.3\%) patient was treated with Cephradine. (Table VII)

Table VII : Antibiotic given to study children $(n=30)$

$\begin{array}{lcc}\text { Antibiotic } & \text { Number } & \text { Percentage (\%) } \\ \text { Ceftriaxone } & 22 & 73.3 \\ \text { Amoxicillin } & 5 & 16.7 \\ \text { Ampicillin+Gentamycin } & 2 & 6.7 \\ \text { Cephradine } & 1 & 3.3 \\ \text { Total } & \mathbf{3 0} & \mathbf{1 0 0 . 0}\end{array}$

\section{Discussion}

In the present study female cases were more than males. Male to female ratio was 2:3 though before puberty boys are more commonly affected than the girls. ${ }^{14}$ considering precipitating factors, acute respiratory tract infection was the most predominant factor. Respiratory Syncytial Virus (RSV) infection of the airway is one of the major precipitants of childhood asthma. ${ }^{15}$ Remaining precipitants are: exposure to dust, cold wave, and emotional upset.

In the present study we found that nebulized salbutamol, and antibiotic were frequently used in treating acute asthma. It is universally recognized that inhaled $\beta_{2}$ agonist (nebulized or MDI) is the mainstay of treatment. ${ }^{16}$ Nebulization was given to all cases with salbutamol and in addition ipratropium bromide was given to $11(36.7 \%)$ cases. Nebulization was given 6 hourly in $26(86.7 \%)$ cases and 8 hourly in $4(13.3 \%)$ cases and the 
doses and ratio of Salbutamol solution to normal saline was not as per national guidelines in most of the cases $6(80 \%)$, but the frequencies were as per national guideline. The technic of nebulization was correct in $10(40 \%)$ cases.

$\beta_{2}$ agonist inhalation is an important basic component of management of asthma exacerbation. It can be given in nebulized from through metered dose inhaler (MDI). ${ }^{12}$ Studies have found that metered dose inhaler with spacer is as effective as salbutamol delivered by nebulizer. ${ }^{17-19}$ According to national guidelines nebulized salbutamol should be given in a dose of 2.5-5 mg mixed with $2-3 \mathrm{ml}$ normal saline. ${ }^{9}$ It is given as stat dose and at an interval of 20 minutes, three such doses can be given in the first hour. Then it can be given at 1-4-hour interval as per need. ${ }^{10}$

In children aged 2-5 years with intermittent viral wheezing, one study showed that a short course of an oral leukotriene antagonist(LTRA) (for 7-20 days commenced at the start of an Upper Respiratory Tract Infection or the first sign of asthma symptoms) reduce symptoms, health care utilization and time off work for the carer. ${ }^{9}$ In contrast another study showed no significant effect on episode free days (primary outcome), Oral Corticosteroid use, health care utilization, quality of life for hospitalization in children with or without a positive Asthma Predictive Index (API). However, activity limitation and a symptom trouble score were significantly improved, particularly in children with a positive API. ${ }^{9}$

All most all the cases were treated with antibiotic (Ceftriaxone, Amoxicillin, Ampicillin, Gentamycin), about three fourth of the cases received Ceftriaxone. Antibiotic therapy is not indicated universally in the management of acute exacerbation of asthma. Antibiotic is indicated in asthmatics in condition like fever with purulent sputum, suspected bacterial sinusitis, concomitant pneumonia, frequent exacerbation of asthma (may be associated with mycoplasma or chlamydial infections). ${ }^{12}$ Use of antibiotic with or without indication was found in the present study.

\section{Conclusion}

The study concluded that nebulized salbutamol with or without ipratropium bromide was given to treat the patient of acute asthma but the dose and ratio of Salbutamol to normal saline was not as per national guideline in all most all the cases. Use of antibiotic was inappropriate. Limitation of the study was that our sample size was small and was taken from only one upazila.

\section{Recommendation}

Appropriate dose and ratio of Salbutamol solution to normal saline is necessary to get the better benefit in treatment of acute asthma.

\section{References}

1. Barua UK1, Saha SK2, Ghosh DK3, Ruble Epidemiological Study on Bronchial Asthma at Shaheed Suhrawardy Medical College Hospital, Dhaka. J Shaheed Suhrawardy Med Coll, 2013; 5(2):77-80.

2. Asthma Association of Bangladesh. National guidelines Asthma \& COPD, 2012; 1-55

3. Hassan MR, Kabir AR, Mahmud AM, et al. Self-reported asthma symptoms in children and adults of Bangladesh: findings of the National Asthma Prevalence Study. Int J Epidemiol. 2002; 31(2):483-488.

4 Jindal SK, Gupta D, Aggarwal AN, Agarwal R, World Health O. Guidelines for management of asthma at primary and secondary levels of health care in India (2005). The Indian journal of chest diseases \& allied sciences. 2005; 47(4):309

5. Rai SP, Patil AP, Vardhan V, Marwah V, Pethe M, Pandey IM. Best treatment guidelines for bronchial asthma. Medical Journal Armed Forces India. 2007; 63(3):264-5. Lai CK, Beasley R, Crane J, et al. Global variation in the prevalence and severity of asthma symptoms: phase three of the International Study of Asthma and Allergies in Childhood (ISAAC). Thorax 2009; 64: 476-483.

6. Lai CK, Beasley R, Crane J, et al. Global variation in the prevalence and severity of asthma symptoms: phase three of the International Study of Asthma and Allergies in Childhood (ISAAC). Thorax 2009; 64: 476-483.

7. Thomas A, Lemanske RF Jr, Jackson DJ. Approaches to stepping up and stepping down care in asthmatic patients. J Allergy Clin Immunol 2011; 128: 915-924.

8. Bonfield TL, Ross KR. Asthma heterogeneity and therapeutic options from the clinic to the bench. urr Opin Allergy Clin Immunol 2012; 12: 60-67.

9. Global initiative for Asthma, Global Strategy for Asthma Management and Prevention, 2019.

10. Asthma Association Bangladesh. National Asthma Guidelines for medical practitioners, Third edition.2005:19-91.

11. Haslett C, Haslett C, Davidson SS. Davidson's principles and practice of medicine. Churchill Livingstone; 2002.513-520.

12. Tattersfield AE. Limitations of current treatment. The Lancet. 1997 Oct 1; 350:S24-7

13. Mollah AH,Ahmed S, Nahar N.Shishuder Asthma O Chikitsha Babosthapon (In bangali),1stedition. Dhaka shishu Kishore Prokashoni: 2000.

14. Anika N,Patrica S .Sx difference inPaediatric and Adult Asthma.Eur Med J(Chemist).2019 Jun;4(2):27-35.

15. AndrewHI, JosephDS, and Donald YI.Allergic disorders in Behram RE, KliegmanMR, Iensen HB, eds. Nelson Textbook of Paediatrics. $17^{\text {Th }}$ ed. India: Thomson Press; 2004.P760-774.

16.Becker JM, Arora A, Scarfone RJ, et al. Oral versus intravenous corticosteroids in children hospitalized with asthma. J Allergy Clin Immunol 1999; 103:586-590.

17. Alam K. Comparative efficacy of salbutamol delivered by nebulizer versus metered dose inhaler. with spacer in acute exacerbation of asthma in children. Thesis: Du, Jan 2003:100-101.

18. National asthma Education and prevention Program. Expert panel report guidelines for diagnosis and management of asthma: Update on selected topics, 2002.Bethesda MD: U.S department of health and Human Resource Services. Public Health Service, National Institute of Health National Heart, Lung and Blood Institute, 2003: NIH publication no 02-5074.

19. Cates CC, Bara A, Crilly JA, Rowe BH. Holding chambers versus nebulizers for beta -agonist treatment of acute asthma. Cochrane Database Syst Rev. 2003; (3):CD000052. 